\title{
Et sykt samfunn eller syke folk?
}

\section{Noe av det mest heldige jeg har opplevd i møte med helsevesenet, var en fastlege som ikke bare så pasienten, men samfunnet rundt meg som helhet.}

Legen jeg var hos, hadde vært lege i en generasjon og diagnostiserte ikke bare meg da jeg var innom, men også den verden vi lever i. Hun så endringer i sykdomsbildet og endringer i samfunnsbildet og sammenhenger mellom de to. For meg som sosiolog var dette selvsagt interessant - for meg som pasient helt avgjørende for selvbildet. Da jeg forlot legekontoret, lurte jeg på hva som var mest sykt, jeg - eller samfunnet jeg lever i. Det lurte nok legen også på. Særlig var hun opptatt av kvinners helse og utfordringer hennes pasienter hadde $i$ forbindelse med graviditet eller med å bli gravide og med å takle alle kravene fra seg selv, fra arbeidsplassen og omverdenen. Hun var både imponert og bekymret over norske kvinner, som sto på og møtte stadig tøffere krav til effektivitet, hjemme og ute. Hadde hun rett i sine observasjoner? Vi damer av i dag hører jo hele tiden hvor heldige vi er, og det er vi jo også, her i likestillingslandet med penger på bok. Så hva er det da som likevel pågår og gjør oss slitne, så slitne innimellom at noen blir syke?

Disse små anekdotene fra min fastlege ble noe av inspirasjonen bak boken Erjeg fri nå? Tidsklemme i verdens beste land, som jeg skrevi 2013. Utgangspunktet var: Hva er det egentlig kvinner mener når de bruker det litt upresise ordet «tidsklemme» for å beskrive hverdagen? Er dette noe vi som samfunn bør ta på alvor eller er det bare klaging fra bortskjemte moderne damer?
For å gjøre 300 sider med bok kort: Jeg fant mye dokumentasjon på at vi godt kan ta tidsklemma på alvor. Når kvinner beskriver at de ikke strekker til på noen arenaer i hverdagen, at de alltid er bakpå, at de har dårlig samvittighet i alle retninger, da er vi innom det som i alle år har vært et gammelt arbeider- og kvinnekrav: Å ha kontroll over livet sitt. Det bør fremdeles være en kamp å kjempe.

Det er fristende å si at kanskje burde en utslitt tidsklemt kvinne (eller mann) ta en terapitime i sosiologi fremfor å gå til psykolog eller til legen? Å forstå mer av verden rundt seg, se strukturer, endringer og sammenhenger, kan om ikke annet gi den enkelte større følelse av kontroll og mindre følelse av skam. For skammen er raskt på plass når man i dag ikke lever opp til vedtatte idealer om hvordan kvinnelivet bør se ut. Men skammen kan raskt forsvinne. En leges kritiske samfunnsblikk kan, på et blunk, fjerne denne destruktive følelsen hos en sliten pasient. Helbredelsen kan starte allerede der.

Målet med å forstå tidsklemma var å forstå hva slags verden utenfor våre små private liv som skaper den. Hva slags samfunnsstruktur, hva slags økonomi og hva slags arbeidsliv har vi som gjør at så mange snakker om at de ikke får hverdagen til?

Det vi har på makroplan, er en nyliberal politikk som forvalter en økonomi som har i seg et premiss om evig vekst. Dette systemet gjør ikke bare at det kan koke i topplokket på enhver kvinne eller mann som er pålagt stadig mer effektiv bruk av sin tid og arbeidskapasitet. Dette systemet gjør også at selve jordkloden for lengst har nådd sitt kokepunkt. Å forstå tidsklemma ga meg et vindu til en viktig verden utenfor.
Også til hva vi ikke verdsetter i et slikt system, verken i kroner eller i status: Det ulønnede arbeidet hjemme som ikke har forsvunnet, selv om både menn og kvinner i dag deltar stadig mer i lønnsarbeid.

To forskningsrapporter fra Karolinska institutet i Stockholm i 2009 viste at det ikke alltid går så bra med den skandinaviske kvinnen, på tross av velferd og likestilling. Kvinner som kombinerer jobb eller studier med barn, er betydelig mer slitne enn sine barnløse medsøstre.

«Vi har en så sterk tro på at kvinner skal kunne arbeide og ha barn. Samtidig har vi ant at det ikke går så bra. Nå er det for første gang bevist i tall. Og så tør vi ikke si det høyt, fordi vi er så redde for et tilbakeslag for kjønnsrollene», sa professor Birgitta Floderus ved Karolinska institutet til Aftenposten 5. september 2009. Kvinner som likevel ikke helt får det til, ender opp med å skylde på seg selv. Floderus sa det var vanskelig å ta tak i temaet fordi det bryter med ideologien om at kvinner kan hvis bare vi vil nok.

Men dette kollektive presset om å være individuelle og forbedre oss selv fremfor verden rundt oss, er også et av nyliberalismens ideologiske grep. Det er typisk for vår tid. Vi er ikke ofre, vi «inntar offerrollen», og da er det også vår plikt å komme oss ut av dem. Er det ikke?

Hvis leger ser samfunnet gjennom sine pasienters historier, så fortell oss om det. Da kan kanskje både vi og samfunnet bli helbredet?

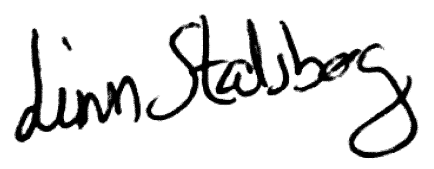

